\title{
The Verification of the Rationality of the Goodwill Measurement Method Based on the Black-Scholes Option Pricing Model
}

\section{— Take the Food and Beverage Industry in Nasdaq Stocks as an Example}

\author{
Yunze Dong ${ }^{1, a}$, Yan Sun ${ }^{2, b^{*}}$ \\ ${ }^{1}$ School of Accounting and Finance, University of Bristol, Bristol, UK \\ ${ }^{2}$ Department of Electrical Engineering, Shandong Agricultural University,Shan dong, China \\ aal18910@bristol.ac.uk \\ b*1520911301@qq.com
}

\begin{abstract}
This article combines the definition of the nature of goodwill, optimizes the traditional margin method, and analyzes the rationality of the margin method based on the Black-Scholes option pricing model; and uses the 2020 data of companies in the food and beverage industry listed on the US stock market in the "Top 500 Brands" as a sample, which verifies the rationality and operability of the method. The results show that the margin method based on the BlackScholes option pricing model has reliability and operability, and can fairly and effectively measure the company's own goodwill.
\end{abstract}

Keywords: self-generated goodwill, initial recognition and measurement of goodwill, margin method, BlackScholes option pricing model

\section{REVIEW OF RELEVANT RESEARCH LITERATURE}

The accounting field has been studying goodwill for more than a hundred years. In the research on goodwill for more than one hundred years, scholars have expressed their opinions and tried to define goodwill from different aspects, summarize the nature of goodwill, and propose fair measurement method. At present, the international practice of only using the M\&A spread method to confirm outsourcing goodwill without confirming self-created goodwill has caused considerable criticism. James et al. [3] emphasized the credibility of goodwill is based on the reliable and convincing measurement. Schultze and Weiler [5] demonstrated the accounting measurement method for goodwill and its subsequent impairment according to IFRS. Abeysekera [1] argued that using market value may not reflect the actual financial value of goodwill. Khaled and David [4] stated that disclosure may be a good choice for recognizing goodwill due to its unreliability. Henning et al. [2] demonstrated an accounting method to value purchased goodwill.

At present, there are two methods for calculating goodwill, the direct measurement method and the indirect measurement method, which are recognized by the academic circles. The direct measurement method treats goodwill as the ability to obtain future excess returns, capitalizes it, and converts it to the present value as the value of goodwill. For example, Yu Weibing and Cong Xinsheng (2004) proposed the excess profit method to calculate goodwill. The value of goodwill is converted into present value by a certain ratio. The specific formula is: the company's future excess profit $\mathrm{P} \times$ the average market profit rate in the previous period. Indirect measurement method, also called margin method, is the difference between the overall value of an enterprise and the sum of the value of the enterprise's tangible assets and identifiable intangible assets. 
The above literature review shows that the current research on goodwill measurement methods at home and abroad is mainly to qualitatively study whether it can reflect the essence of goodwill and whether the uncertain factors are controllable, etc., do not use the existing actual operation and optimization of capital market data is still a "black box" as it is tricky to select indicators that reflect different aspects of the enterprise. The research in this paper attempts to optimize the margin method by using the Black-Scholes option pricing model to enhance its operability, and uses the 2020 data of the US food and beverage industry to conduct reliability tests.

\section{CONSTRUCTION OF THE GAP METHOD MODEL BASED ON THE BLACK-SCHOLES OPTION PRICING MODEL}

The appraised value of goodwill $(\mathrm{G})=$ the appraised value of the company's overall assets - the sum of appraised values of individual assets of the company

Here, it can be simplified, and the steps are as follows: The assessed value of goodwill $(\mathrm{G})=$ the discounted value of the company's current and future cash flows total liabilities - estimated equity value $=$ (Corporate Value + Cash) - Total Liabilities - Equity Appraisal Value $=($ Company Market Value + Total Liabilities Cash) + Cash - Total Liabilities - Equity Appraisal Value $=$ Company Market Value-Equity Appraisal Value

In the simplified formula of the difference method, the market value of the company (Market Value) is the number of outstanding shares multiplied by the closing price of the day, and how to accurately confirm the equity evaluation value is currently not a reliable measurement method, and it is subject to the confirmation process. Due to the influence of some human factors, there is often a large gap between the assessed goodwill and the selfgenerated goodwill actually owned by the company.

As we all know, at any time, a company has assets (A) $=$ liabilities $(\mathrm{L})-$ owner's equity $(\mathrm{E})$, that is, owner's equity $(\mathrm{E})=\operatorname{assets}(\mathrm{A})-$ liabilities $(\mathrm{L})$. However, this algorithm can only represent the amount of owners' equity at this point in time, and does not include predictions of future trends. Since the mathematical relationship between equity, assets and liabilities when calculating equity valuation is consistent with the mathematical relationship between option price, stock current price and strike price at option valuation, we can apply the Black-Scholes option pricing model to calculate equity valuation. Here, the owner's equity of the company can be regarded as a call option, that is, the residual claim against the company. The result of executing this option means that the company is liquidated. When the company's total assets are greater than the total debt, the equity assessment value is the difference between the company's total assets and the total liabilities; when the company's total assets are less than the total liabilities, the equity assessment value is zero.

In summary, the following formula can be obtained

$$
\begin{gathered}
\mathrm{G}=\mathrm{MV}-\left[\mathrm{A} * \mathrm{~N}\left(d_{1}\right)-\mathrm{L} e^{-r t} * \mathrm{~N}\left(d_{2}\right)\right](1) \\
d_{1}=\frac{\left[\ln \left(\frac{A}{L}\right)+\left(r+\frac{\sigma^{2}}{2}\right) T\right]}{\sigma \sqrt{T}}(2) \\
d_{2}=d_{1}-\sigma \sqrt{T}(3)
\end{gathered}
$$

Among them, $\mathrm{G}$ is the value of the company's selfcreated goodwill (Goodwill); MV is the market value of the company (Market Value), that is, the number of shares outstanding $\times$ the closing price of the day; $\mathrm{A}$ is the total assets of the company (Assets); L is the total liabilities of the company (Liability); $r$ The risk-free interest rate is generally taken as the one-year treasury bond interest rate of the country where the company is located; $\mathrm{T}$ is the validity period of goodwill, generally taken as 5 years (according to the conclusions of empirical research, the company's current excess profitability can be achieved in the next five years. Keep, and then slowly trend towards the market average); Chu is the coefficient of variation of the stock price (standard deviation/closing average price).

Correspondingly, for the above formula, the following assumptions need to be made: (1) The risk-free interest rate $r$ is known, a constant, and does not change with time; (2) The change in total assets A conforms to a random walk, but this A random walk can make the return on stocks log-normally distributed; (3) The total debt L is a constant within a five-year period and does not change with time.

\section{SELECTION OF SAMPLE DATA}

The author selected a total of seven samples of food and beverage companies listed in the United States from the "2020 (13th) Top 500 World Brands" rankings released by the World Brand Lab.

Unlike the ranking of the "Top 500 Companies in the World" selected by Fortune Magazine each year based on operating income, the "Top 500 World Brands" ranking is based on the brand's global influence. Brand influence (Brand Influence) refers to the brand's ability to open up the market, occupy the market and make profits. According to the three key indicators of brand influence, namely market share (Share of Market), brand loyalty (Brand Loyalty) and global leadership (Global Leader ship), the World Brand Lab scored 8,000 well-known brands around the world, and finally selected the 500 most influential brands in the world. Such ranking is based on a definition closer to goodwill.

The author chose the food and beverage industry in the US stock market to eliminate the influence of the stock market and industry on the results of goodwill measurement: the US stock market is a mature stock market with strong data reliability and fairness; the food 
and beverage industry has relatively small fluctuations in demand, and there is no seasonal fluctuation, the relationship between supply and demand is relatively stable, and its data is less disturbed by other factors.

\section{DESCRIPTIVE STATISTICS OF SAMPLE DATA}

The author compiled the food and beverage industry companies listed on the U.S. stocks in the "2020 (13th) World Brand Top 500" rankings, and performed descriptive statistics on the closing prices of these companies on the 252 trading days of U.S. stocks in 2020 . As shown in Table 1. The following raw data are from Wind. The risk-free rate $\mathrm{r}$ is $1.5 \%$.

Table 1. Ranking of U.S. food and beverage companies in the top 500 and descriptive statistical results of related data

\begin{tabular}{|c|c|c|c|c|c|c|c|}
\hline Rank & brand name & $\begin{array}{c}\text { Tradable } \\
\text { shares }\end{array}$ & $\begin{array}{c}\text { Closing } \\
\text { price }\end{array}$ & $\begin{array}{c}\text { Closing } \\
\text { average }\end{array}$ & $\begin{array}{c}\text { Standard } \\
\text { deviation }\end{array}$ & $\begin{array}{c}\text { Total assets } \\
\text { (US\$ billion) }\end{array}$ & $\begin{array}{c}\text { Total liabilities } \\
\text { (US\$ billion) }\end{array}$ \\
\hline 5 & Coca-Cola & 4,28800000 & 41.46 & 43.545 & 1.65 & 82.270 & 64.050 \\
\hline 15 & Pepsi & $1.428,00000$ & 104.63 & 103.667 & 3.68 & 74.129 & 62.930 \\
\hline 238 & Kelogg's & 351069334 & 73.71 & 76.418 & 3.63 & 15.111 & 13.185 \\
\hline 240 & CampellSou & $307,051,879$ & 60.47 & 59.537 & 4.15 & 7.837 & 6.081 \\
\hline 359 & Hersheys & $151,639,958$ & 103.43 & 96.912 & 7.56 & 5.524 & 4.697 \\
\hline 424 & TysonFoods & $286,947,904$ & 61.68 & 66.089 & 6.56 & 22.373 & 12.749 \\
\hline 486 & ConAgraFoo & $424435,212,4$ & 39.55 & 43.955 & 3.48 & 11.425 & 6.898 \\
\hline
\end{tabular}

5. THE MEASUREMENT RESULT OF SELF-CREATED GOODWILL USING THE MARGIN METHOD MODEL BASED ON THE BLACK-SCHOLES OPTION PRICING MODEL
The author brings the data in Table 1 into the margin method based on the Black-Scholes option pricing model, and the value of the eight companies' self-generated goodwill is shown in Table 2 .

Table 2. Ranking of U.S. food and beverage companies in the top 500 and calculation results of their own goodwill

\begin{tabular}{|c|c|c|c|c|}
\hline Rank & brand name & $\begin{array}{c}\text { Market value } \\
\text { (US\$ billion) }\end{array}$ & $\begin{array}{c}\text { Equity appraisal value } \\
\text { (US\$ billion) }\end{array}$ & $\begin{array}{c}\text { Self-created goodwill } \\
\text { (US\$ billion) }\end{array}$ \\
\hline 5 & Coca-Cola & 177.780 & 22.848 & 154.932 \\
\hline 15 & Pepsi & 149.412 & 15.748 & 133.664 \\
\hline 238 & Kelogg's & 25.877 & 2.891 & 22.986 \\
\hline 240 & CampellSoup & 18.567 & 2.202 & 16.366 \\
\hline 359 & Hersheys & 15.684 & 1.201 & 14.484 \\
\hline 424 & TysonFoods & 17.699 & 10.547 & 7.152 \\
\hline 486 & ConAgraFoods & 17.213 & 5.026 & 12.187 \\
\hline
\end{tabular}




\section{ANALYSIS OF THE RATIONALITY OF THE RESEARCH RESULTS}

It can be seen from Table 2 that, with the exception of ConAgra Foods, the relationship between the value of self-generated goodwill calculated by the abovementioned seven companies using the margin method based on the Black-Scholes option pricing model and its rankings in the Top 500 World Brands are exactly the same. According to the author's analysis, the main reason for the discrepancy between the goodwill value of ConAgra and the ranking is: the company's business is concentrated in North America, and there is almost no business in other regions, so its brand value in North America is significantly higher than that in other regions. The data selected here is U.S. stock data, which reflects the influence of this brand in the United States; and the ranking reflects the influence of this brand on a global scale. Therefore, there will be cases where the value of goodwill of a few companies does not match the ranking. The above results show that the margin method based on the Black-Scholes option pricing model proposed in the previous article is reliable and operable, and can fairly and effectively measure the amount of the company's self-generated goodwill.

\section{CONCLUSION}

\subsection{Research conclusion}

The above research results show that by introducing the Black-Scholes option pricing model and optimizing the original margin method, the improved margin method based on the Black-Scholes option pricing model can measure self-generated goodwill more scientifically and reasonably. The contributions of the above research are: first, it improves the original margin method, and theoretically analyzes that the margin method based on the Black-Scholes option pricing model conforms to the essence of goodwill; second, the use of the U.S. stock food and beverage industry 2020 The annual data proves that the margin method based on the Black-Scholes option pricing model is highly operable and not subject to human factors; third, the data of the U.S. food and beverage industry for 2020 is substituted to verify the use of options based on Black-Scholes The reasonableness of the value of self-generated goodwill calculated by the margin method of the pricing model. The limitations of the above research are as follows: First, this method is based on company stock price data and is not applicable to unlisted companies; second, this method is based on certain assumptions, which limits of the use of BlackScholes option pricing model; third, this method will be affected by stock market factors and industry factors; fourth, this method needs to be verified by more market data.

\subsection{Policy implications}

In the short term, before discovering a reliable measurement method for self-generated goodwill, the author believes that the "goodwill" account should be renamed the "merger spread" account. Because the current standard stipulates that the "M\&A spread method" is adopted. On the one hand, this method does not conform to the academic definition of the essence of goodwill; on the other hand, it can only confirm the goodwill of the company's mergers and acquisitions, but not the self-generated goodwill. As a result, the so-called "goodwill" account actually only contains the Merger goodwill of the acquirer. In the long run, according to the logical order of time, the author believes that the goodwill accounting standards should be regarded as an independent one in the "Accounting Standards for Business Enterprises", which is conducive to systematic research on goodwill. Furthermore, the author believe we may be supposed to stop the use of the equity combination method and the spread method and standardize the use of the margin method. Although the current separation method is greatly affected by other interference factors, theoretically speaking, the latter is more in line with the essence of goodwill than the former. Finally, establishing a "goodwill" account to fully measure goodwill including self-generated goodwill and purchased goodwill is reliable and has horizontal and vertical comparability and auditability.

\section{REFERENCES}

[1] Abeysekera, Indra. (2012). Measuring and Recognizing the Value of Purchased Goodwill: A Note on Market Value Measurement Method. Academy of Taiwan Business Management Review, $8(3), 57-65$.

[2] Henning, S., Lewis, B., \& Shaw, W. (2000). Valuation of the Components of Purchased Goodwill. Journal of Accounting Research, 38(2), 375-386.

[3] James, C., McCroskey \& Jason J. Teven. (1999). Goodwill: A reexamination of the construct and its measurement, Communication Monographs, 66(1), 90-103.

[4] Khaled Al Jifri \& David Citron. (2009). The ValueRelevance of Financial Statement Recognition versus Note Disclosure: Evidence from Goodwill Accounting, European Accounting Review, 18(1), 123-140.

[5] Schultze, W. and Weiler, A. (2010). "Goodwill accounting and performance measurement", Managerial Finance, 36(9), 768-784. 